\title{
The Combination of DEMATEL, ANP, and IPMS Methods for Performance Measurement System Design: A Case Study in KOLAT KOARMATIM
}

\author{
Marsetio $^{1}$, Amarulla Octavian ${ }^{1}$, Siswo Hadi Sumantri ${ }^{2}$, Ahmadi $^{2}$, Rajab Ritonga ${ }^{3}$ \\ and Supartono ${ }^{2}$ \\ ${ }^{1}$ Indonesia Defense University, Bogor, West Java, Indonesia \\ ${ }^{2}$ Sekolah Tinggi Angkatan Laut, Surabaya, East Java, Indonesia \\ ${ }^{3}$ Universitas Prof Dr Moestopo (Beragama), Jalan Hang Lekir, Jakarta, Indonesia \\ ${ }^{4}$ Biro Klasifikasi Indonesia, Jakarta, Indonesia \\ *Corresponding author: rajab.ritonga@dsn.moestopo.ac.id
}

\begin{abstract}
The use of Integrated Performance Measurement System (IPMS) method in an institution under Indonesian Naval Forces (TNI AL) is intended to improve the integrated performance measurement system which generally is only based on financial accountability report. This paper presents the combination of DEMATEL, ANP, and IPMS methods for performance measurement system design. The method was designed at KOLAT KOARMATIM to analyze the achievement of the 2015 and 2016 Work Programs with 23 Key Performance Indicators (KPIs), based on stakeholders' requirements of KOLAT KOARMATIM. To indicate the impact among criteria, DEMATEL is used to then determine the weight of each sub criteria and their respective KPIs identified. Based on the scoring system using Objective Matrix (OMAX), from the 2015 performance measurement conducted, the Total Performance Index obtained is amounted to 7.697; in addition, by using Traffic Light System, it is situated in the Yellow category, meaning that the performance measurement target (achievement) in 2015 has not been reached despite nearing the desired threshold target; there are 11 green KPIs, 11 yellow KPIs, and 1 red KPI. The performance measurement results in 2016 show that the Total Performance Index is amounted to 8.344 as a result of scoring by using OMAX, and by using the Traffic Light System, it is situated in the Green category, meaning that the performance measurement target (achievement) has been reached (satisfactory) with the dispersion including 16 green KPIs, 6 yellow KPIs and 1 red KPI. Red KPI is the KPI below the targets set by KOLAT KOARMATIM; hence it becomes a top priority for the implementation of improvement. Two KPIs in the red indicator include the Combat Task Exercise of The Republic of Indonesia Warship (GLAGASPUR KRI $(U)$ ) and the Development Planning (RENBANG).
\end{abstract}

Keywords: ANP; DEMATEL; IPMS; KPI; OMAX; Traffic light system

\section{Introduction}

The Training Command of Eastern Region Fleet of the Indonesian Navy or abbreviated as KOLAT KOARMATIM is the educational executive command structured directly below the Commander-in-Chief of Eastern Region Fleet. KOLAT KOARMATIM principal duty is to foster professionalism among the Eastern Region Fleet Command (KOARMATIM) personnel through the Integrated Fleet Weapons System (SSAT), courses and trainings on naval warfare tactics and techniques. The Development of Human Resources (HR) is a continuous process in line with the expectation of the Indonesian Naval Forces (TNI-AL) to generate professional personnel with high integrity 
in order to be able to face the challenges of the increasingly complex and dynamic task ahead as the result of the development of the strategic environment and rapid development of technology. One of the efforts of the initial development of human resources in the KOLAT KOARMATIM personnel is through training that is directed, programmed and measured on the KOLAT KOARMATIM which serves as a training center. KOLAT KOARMATIM is a training center which has the main task in the development of operational capability in the field of maritime, engineering, informatics, electronic communications, navigation electronics, electronic control of weapons, and consolidation of combat ships team through the implementation of various forms of exercises by using the instructional equipment and the instructional supporting equipment (alongins) available.

The operation and exercise activities executed by KOLAT KOARMATIM are quite many, covering a wide area, including almost all regions of eastern Indonesia. As an overview of the activities carried out in 2015, they included 16 course activities, 13 InService-Training $(L D D)$ activities, 13 Training Administration (Binlat) activities, the implementation of 25 Combat Task Exercise Tests of the Republic Indonesia Warship Level 1 (Uji Glagaspur KRI L1), the implementation of 25 Uji Glagaspur KRI L2, the implementation Glagaspur Test of Special Forces (Pasukan Khusus) K.1: 9 times, K.2: 6 times and K.3: 4 times, the implementation of Pangkalan Glagaspur Test P.1: 10 times and P.2: 10 times, as well as the implementation of the Glagaspur Test of Aircraft U1: 3 times. Certainly, this is not an easy task for the limited personnel and limited facilities/infrastructure. According to the data derived from KOARMATIM Operational Staff, it is mentioned that, in 2015, there were accidents of 4 Indonesian warships (KRI), and 3 similar cases in 2016. This shows a decrease in the level of skills and professionalism of the KOARMATIM crew; thus, the role of KOLAT KOARMATIM as a training institution needs to be improved through Courses and KRI, Head of Machinery Department Course (Kursus Kadepsin) or Duty Officer Course, so that the readiness of the naval soldiers in manning the Main Equipment and Weapon System (Alutsista) can be justified.

The performance measurement is not only necessary to evaluate the activities that have been carried out, but further expected to be able to provide better solutions and planning ahead. KOLAT KOARMATIM should be able to conquer more complex challenges and coordinate the needs of the stakeholders, in this case KRI and Naval Bases under the KOARMATIM lines. Performance measurement within an organization is an important thing to do, for all organizations need to evaluate and plan the working performance, resulting in the improved performance process that is continuous and consistent [1-3]. The existing difficulty is that the performance measurement of an organization focuses more on the financial perspective of the organization [4-7]. Certainly, the measurement process would be a little more complicated for a non-profit organization. However, along with the rapid development of performance measurement study, such matter is not a big problem. Now, there have been a lot of performance measurement methods, such as Balanced Scorecard [8-12], Performance Prism [13-16], and Integrated Performance Measurement System (IPMS) [17-21].

According to Maulidia, et al. in [20], Integrated Performance Measurement System (IPMS) is a method aiming to describe the performance measurement system in a proper sense, in the form of integration as effectively and efficiently as possible. This method can be used to complement the performance measurement that has been based solely on the principle of accounting, conducted by an independent auditor. Yet, other aspects also affect the performance of companies, such as the condition of employees, customer satisfaction, and etc., because essentially, a company is an integration of multiple stakeholders. The implementation also has done well on profit and non-profit organizations; in which IPMS method emphasizes on non-profit organizations and on the interests of stakeholders. According to Liang et al. in [22], the application of Decision- 
Making Trial and Evaluation Laboratory (DEMATEL) is used to determine the relationship that occurs between performance measurement criteria existing in an organization as well as to determine the dominant criteria. The DEMATEL uses direct relationship diagram divided into two groups, namely, case group and consequence group [23-26]. The DEMATEL is an effective method for building and analyzing structure models generally used to find the relationship of social phenomena and solution of dependency on each element. According to [23-26], DEMATEL can be said as a "filter" method, used before the criteria are processed by expert respondents who are competent in the company. This would affect the determination of more focused criteria, representing the major conditions of the company. In addition, the network formed by DEMATEL can be used in ANP. To obtain the Scoring System, the method of Objective Matrix (OMAX) and Traffic Light System (TLS) are used. By looking at the benefits of the use of the methods above, it is proper to implement them on KOLAT KOARMATIM performance measurement, so that the results can be more relevant.

Based on above explanation, this paper presents the combination of DEMATEL, Analytic Network Process (ANP), and IPMS methods for performance measurement system design. The method was designed at KOLAT KOARMATIM to analyze the achievement of the 2015 and 2016 Work Programs with 23 Key Performance Indicators (KPIs), based on stakeholders' requirements of KOLAT KOARMATIM.

The rest of this paper is organized as follow: Section 2 presents review on KOLAT KOARMATIM organization, integrated performance measurement system, decision making trial evaluation and laboratory, analytic network process, and OMAX scoring and traffic light systems. Section 3 presents proposed method. Section 4 presents obtained results and following by discussion. Finally, Section 5 concludes this work.

\section{Rudimentary}

\subsection{KOLAT KOARMATIM Organization}

The Training Command of Eastern Region Fleet of the Indonesian Navy (KOLAT KOARMATIM) is an educational executive command in the scope Eastern Fleet which has a strategic role. KOLAT KOARMATIM has the task of fostering professionalism of KOARMATIM naval soldiers, through organizing courses and trainings in all fields related to the development and improvement of the KOARMATIM crews. In the implementation of these duties, the Eastern Region Fleet C-in-C (Pangarmatim) mentioned that KOLAT KOARMATIM organizes some functions including to prepare and implement training guidance plans and programs for both trainings related to the position and trainings in the service of KOARMATIM environment, as well as to organize and prepare technical instructions in the field of education and training (Organization, Duties, and Procedure Execution Manual/Bujuklak Orgaspros of the KOLAT KOARMATIM).

\subsection{Integrated Performance Measurement System (IPMS)}

Integrated Performance Measurement System (IPMS) model is a model of performance measurement system developed by the Centre for Strategic Manufacturing of the University of Strathclyde, the UK. This model was developed in order to provide performance measurement system that provides structure as well as robust, integrated, efficient, and effective component selection as a new model. IPMS model is constructed based on the work of the academicians based on best industry practices in the past and in the present [27-29]. The starting point of this model uses stakeholder requirements. The design of the performance measurement system is only performed on one business unit. This causes several phases that should be conducted, such as reference model and audit methods that are no longer used. From the best experiences, similar industry directly designs the performance measurement system in four levels identified as metrics that can 
be measured, known as the key performance indicator (KPI). KPI is determined by stakeholder requirements, external monitor, and objectives. The performance measurement system design process runs in a top-down system, from the business level to the level of activity. Each element will be explained as follows:

a. The Identification of Stakeholder Requirements

On every level of business (organization), stakeholders or parties interested in the business should be identified. Furthermore, their demands or requirements on the businesses (stakeholder requirements) are identified. Stakeholders may include; shareholders, social environment, employees, government/other institutions.

b. The Determination of Objectives

The setting of the objectives should be based on the engagement and priority of common interest development along with appropriate targets and timescales. The objectives should also be based on the ideas of several inputs, namely: stakeholder requirements, world-class business performance and practices, competitive gaps and plans of competitors. The existing level of performance in which the organization is able to achieve although with various constraints is called a realistic target. The existing level of performance in which the organization has the ability to achieve by eliminating various constraints is called potential targets.

\section{c. KPI Setting}

Having obtained the objectives, then measurements on each objective to determine the level of success are conducted. To do these measurements, the indicators of success of the objectives must be determined. These indicators are called the key performance indicators (KPIs). In other words, KPI is a measure to determine the achievement level of each objective.

d. Performance Measures

An organization must have performance measurements that really show the performance level achieved, and demonstrate how successful the achievement of objectives at each level is. The performance measurements for each business have differences, therefore, they requires carefulness and good understanding of the business in order to obtain the correct performance measurement. To obtain the exact performance measurement or the right KPI, a validation of the KPI created needs to be done. Then, when the KPI is valid, it is specified to facilitate the measurement process. KPI specification process is performed to determine a clear description of KPIs, objectives, relevance to the objectives, targets and thresholds, formula/ways of measuring KPIs, measurement frequency, review frequency, the ones who measure and what they do (See Table 1).

Table 1. Comparison of the Three Models of Performance Measurements

\begin{tabular}{|c|c|c|c|c|}
\hline No & $\begin{array}{c}\text { Condition of KOLAT } \\
\text { KOARMATIM }\end{array}$ & IPMS & Balanced Scorecard & $\begin{array}{c}\text { Performance } \\
\text { Prism }\end{array}$ \\
\hline 1 & $\begin{array}{l}\text { Non-profit organization } \\
\text { that is not oriented to } \\
\text { financial aspects. }\end{array}$ & $\begin{array}{l}\text { IPMS does not } \\
\text { require the } \\
\text { organization to be } \\
\text { profit or non-profit, } \\
\text { and IPMS is not } \\
\text { based on financial } \\
\text { aspects }(* * *) \text {. }\end{array}$ & $\begin{array}{l}\text { Using the financial } \\
\text { aspect as one of the } \\
\text { perspectives and even } \\
\text { as the culmination of } \\
\text { performance } \\
\text { measurement design. }\end{array}$ & $\begin{array}{l}\text { Based on } \\
\text { product group. }\end{array}$ \\
\hline 2 & $\begin{array}{l}\text { Not directly clarify the } \\
\text { vision and mission into } \\
\text { the organization's } \\
\text { strategy to become a } \\
\text { determining activity or } \\
\text { activity process occurring } \\
\text { within the organization. }\end{array}$ & $\begin{array}{l}\text { Not based on the } \\
\text { interpretation of } \\
\text { vision and mission } \\
\text { into the } \\
\text { organization's } \\
\text { strategy }(* * *) \text {. }\end{array}$ & $\begin{array}{l}\text { A mechanical tool to } \\
\text { measure the } \\
\text { implementation plan } \\
\text { and the results of the } \\
\text { strategies that have } \\
\text { been set by an } \\
\text { organization. }\end{array}$ & $\begin{array}{l}\text { Not based on } \\
\text { the strategy of } \\
\text { the } \\
\text { organization. }\end{array}$ \\
\hline
\end{tabular}




\begin{tabular}{|c|l|l|l|l|}
\hline 3 & $\begin{array}{l}\text { Having multiple } \\
\text { stakeholders and multiple } \\
\text { activities in which each } \\
\text { stakeholder plays a very } \\
\text { important role on its } \\
\text { development. }\end{array}$ & $\begin{array}{l}\text { IPMS is based on } \\
\text { stakeholder } \\
\text { requirements }(* * *) .\end{array}$ & $\begin{array}{l}\text { Not based on } \\
\text { stakeholder } \\
\text { requirement. }\end{array}$ & $\begin{array}{l}\text { Not based on } \\
\text { stakeholder } \\
\text { requirement. }\end{array}$ \\
\hline $\mathbf{4}$ & $\begin{array}{l}\text { Kolat aims to improve } \\
\text { the professionalism and } \\
\text { carry out the aptitude } \\
\text { test. }\end{array}$ & $\begin{array}{l}\text { Key performance } \\
\text { indicator is a direct } \\
\text { measure and pseudo } \\
\text { measure }(* * *) .\end{array}$ & $\begin{array}{l}\text { Key performance } \\
\text { indicator is } \\
\text { quantitative and } \\
\text { qualitative }(* * *) .\end{array}$ & $\begin{array}{l}\text { Key } \\
\text { performance } \\
\text { indicator is } \\
\text { qualitative. }\end{array}$ \\
\hline
\end{tabular}

Note: $* * *$ demonstrates the excellence of the model compared to the other models

\subsection{Decision Making Trial Evaluation and Laboratory (DEMATEL)}

The DEMATEL method is a method that was first developed by the Battelle Memorial Institute (BMA) in 1971 at the Geneva Research Center [30]. In that year, DEMATEL method was used to assist in the research and analysis of complex problems. The original DEMATEL aimed to fragment antagonistic phenomena in social field and integration of decision-making. According to Wu and Lee [31] in Ranjbar and Shirazi [32], DEMATEL is an appropriate method used to design and analyze complex problems by creating a structured model of causal relationship between factors in a system. Complex problem solving using DEMATEL will be presented graphically, so as to facilitate the researchers to perform troubleshooting and system planning. Phases in DEMATEL method can be seen in Figure 1 below:

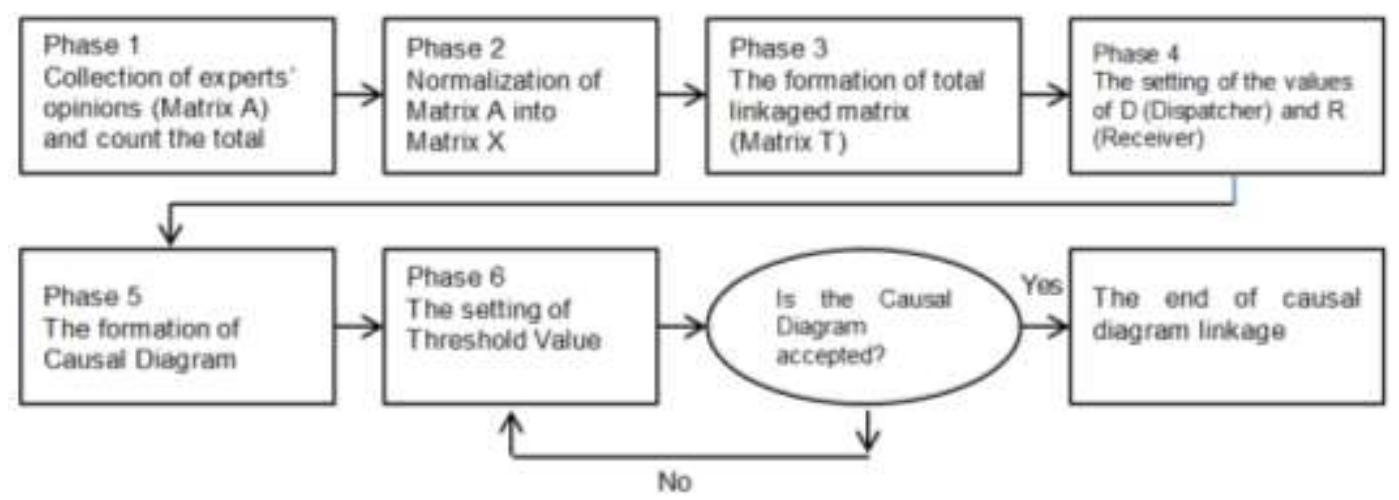

Figure 1. Phases in DEMATEL Method

\subsection{Analytic Network Process (ANP)}

Analytic Network Process (ANP) is a mathematical theory that allows a decision maker deal with dependent factors and feedback systematically. ANP is one of the methods of decision-making based on the number of criteria or Multiple Criteria Decision Making (MCDM). The ANP was developed by Saaty in [33] which is a new approach to qualitative method. The preceding method development is the Analytic Hierarchy Process (AHP).

This process of paired comparison uses numbers/scales that reflect the interest/preference level of a decision element with other decision elements in the same hierarchical level. This helps the decision maker to compare each element of the decision, because in each paired comparison, it only concentrates on two of them [33]. Table 2 below shows the scale of paired comparison: 
Table 2. Paired Comparison Scale [33]

\begin{tabular}{|c|l|}
\hline Interest Level & \multicolumn{1}{c|}{ Definition } \\
\hline 1 & Both elements are equally important. \\
\hline 3 & One element is quite more important than other elements. \\
\hline 5 & $\begin{array}{l}\text { One element is actually more important than other } \\
\text { elements. }\end{array}$ \\
\hline 7 & One element is clearly more important than other elements. \\
\hline 9 & $\begin{array}{l}\text { One element is absolutely more important than other } \\
\text { elements. }\end{array}$ \\
\hline $2,4,6,8$ & The median between two adjacent values. \\
\hline
\end{tabular}

\subsection{OMAX Scoring and Traffic Light Systems}

The scoring system is used after the results of the performance measurement system design has been completed. The next stage is the performance measurement phase by collecting the performance data of the measurement year in the form of data of realization or measurement result achievement and the targets set by the organization. According to Balkan in [34], the function of OMAX is to match the scale of values of each indicator, so that the achievement on each parameter can be used to determine the overall performance. The Objective Matrix method combines the criteria of productivity into an integrated form related to each other. Below a framework overview of the Objective Matrix method is given (see Figure 2).

\begin{tabular}{|c|c|c|c|c|c|c|c|}
\hline \multirow{2}{*}{${ }^{A} \downarrow$} & \multicolumn{2}{|c|}{$\begin{array}{l}\text { PERFORMANCE } \\
\text { KRITERIA }\end{array}$} & KPI & KPI & KPI & KPI & KPI \\
\hline & \multicolumn{2}{|c|}{ PERFORMANCE } & & & & & \\
\hline \multirow{10}{*}{ B } & \multirow{10}{*}{$\begin{array}{l}\text { 命 } \\
\text { 甭 }\end{array}$} & 10 & & & & & \\
\hline & & 9 & & & & & \\
\hline & & 8 & & & & & \\
\hline & & 7 & & & & & \\
\hline & & 6 & & & & & \\
\hline & & 5 & & & & & \\
\hline & & 4 & & & & & \\
\hline & & 3 & & & & & \\
\hline & & 2 & & & & & \\
\hline & & 1 & & & & & \\
\hline \multirow{4}{*}{ c } & & 0 & & & & & \\
\hline & \multicolumn{2}{|c|}{ SCORE } & & & & & \\
\hline & \multicolumn{2}{|c|}{ WEIGHT } & & & & & \\
\hline & \multicolumn{2}{|c|}{ VALUE } & & & & & \\
\hline
\end{tabular}

Figure 2. Objective Matrix (OMAX) Framework

The result obtained from the scoring calculation in the supplier performance evaluation system is applied in the Traffic Light System. This is done to compare the target performance with the actual supplier performance [1-3] This system clarifies the performance of suppliers into three (3) groups of colors: green, yellow, and red. Each has a different meaning [35]:

a. Green is given to the KPI reaching level 8 to 10 . It means the achievement of the performance indicators is achieved, equal or even exceeding the target.

b. Yellow is given to the KPI reaching level 4 to 7 . It means that the achievement of performance indicators has not been achieved even though the value is close to the target. Hence, the management should be careful with any possibilities that will emerge. 
c. Red is given to the KPI reaching level 0 to 3 . It means that the achievement of the performance indicators is really below the set targets and it requires immediate upgrading.

\section{Proposed Method}

The research was conducted by collecting data and information directly from the stakeholders of KOLAT KOARMATIM. Instruments used in this study are questionnaires. Questionnaires were distributed to all stakeholders of KOLAT KOARMATIM, namely, KRI, staff, Special Forces, Navy Main Base (Lantamal/Lanal), as well as KOLAT KOARMATIM staff. In addition to using questionnaires, the data collection was conducted by observation, interview, documentation, and literature review to obtain primary data for the study. The procedure in this study begins with field study and literature study, and then proceeds by identifying the issues on the company and setting the objective of the study. The next step is to collect the data both primary data and secondary data needed in the study. Then the data are processed by using methods of IPMS, DEMATEL, ANP, and scoring systems that includes OMAX and the Traffic Light System. From the data processing results and analysis, conclusions and suggestions are taken.

\section{Results and Discussion}

This section presents obtained results and following by discussion.

\subsection{Validated Stakeholder Requirements}

Table 3 below presents the results of stakeholder requirements that have been validated.

\section{Table 3. The Results of Stakeholder Requirements that Have Been Validated}

\begin{tabular}{|c|c|c|c|c|}
\hline NO & CRITERIA & SEQUENCE & REQUIREMENT & SOURCE \\
\hline 1 & 2 & 3 & 4 & 5 \\
\hline \multirow[t]{3}{*}{1} & Safety & 1 & Personnel Safety & $\begin{array}{l}\text { Commander of Training } \\
\text { Command (Dankolat) }\end{array}$ \\
\hline & & 2 & Material Security & Dankolat \\
\hline & & 3 & Document Security & Dankolat \\
\hline \multirow[t]{3}{*}{2} & $\begin{array}{l}\text { Operation and } \\
\text { Exercise }\end{array}$ & 4 & $L, U, K$ and $P$ Tests & $\begin{array}{l}\text { Glagaspur Commander, KRI } \\
\text { Commander, Naval Base } \\
\text { (Lanal) }\end{array}$ \\
\hline & & 5 & Courses, LDD, Binlat & $\begin{array}{lr}\text { Operation } & \text { Assistance } \\
\text { Commander (Dan Duk Ops), } \\
\text { KRI } & \text { Commander, } \\
\text { KOARMATIM } & \text { Operation } \\
\text { Staff } & \end{array}$ \\
\hline & & 6 & $\begin{array}{l}\text { Implementation of coach } \\
\text { qualification standards }\end{array}$ & KRI Commander \\
\hline \multirow[t]{5}{*}{3} & Personnel & 7 & Press Fulfillment & Kolat Administration Forces \\
\hline & & 8 & $\begin{array}{l}\text { Improvement of } \\
\text { Discipline }\end{array}$ & Work Programs (Proker) \\
\hline & & 9 & Improvement of English & Proker \\
\hline & & 10 & Physical Fitness & Proker \\
\hline & & 11 & $\begin{array}{l}\text { Improvement of } \\
\text { Character-Building }\end{array}$ & Proker \\
\hline 4 & Material & 12 & Management of stationery & Pas Program \\
\hline
\end{tabular}




\begin{tabular}{|c|l|c|l|l|}
\hline & 13 & $\begin{array}{l}\text { Report of State } \\
\text { Possession Accounting } \\
\text { System (Simak BMN) }\end{array}$ & Proker \\
\hline & & 14 & $\begin{array}{l}\text { Addition of Instructional } \\
\text { Equipment }\end{array}$ & Proker, KRI Commander \\
\hline 5 & $\begin{array}{l}\text { Programs and } \\
\text { Budgets }\end{array}$ & 15 & $\begin{array}{l}\text { Development Planning } \\
\text { Renbang) }\end{array}$ & Proker \\
\hline 6 & Methods & 16 & Budgeting Management & Proker \\
\hline & & 18 & $\begin{array}{l}\text { Software Training } \\
\text { Curriculum }\end{array}$ & $\begin{array}{l}\text { KRI Commander, Lanal, } \\
\text { Proker }\end{array}$ \\
\hline
\end{tabular}

\subsection{The Objectives Setting}

Objectives are set based on the stakeholder requirements that have been identified respectively. Identification of the objectives was carried out along with the Kolat crew by interviews and it obtained results as written in Table 4 as follows:

\section{Table 4. Identification of the Objectives Conducted Along with the Training Command (Kolat)}

\begin{tabular}{|c|c|c|c|}
\hline No & Requirement & Objectives & Key Performance Indicator \\
\hline 1 & Personnel Safety & 1. No sabotage by outsider & $\begin{array}{l}\text { Ratio of total sabotage and } \\
\text { strangers visiting annually }\end{array}$ \\
\hline 2 & Material Security & $\begin{array}{l}\text { 2. No weapons are lost or } \\
\text { damaged }\end{array}$ & $\begin{array}{l}\text { Ratio of lost/damaged weapons } \\
\text { and available weapons annually }\end{array}$ \\
\hline 3 & Document Security & $\begin{array}{l}\text { 3. Documentation checking } \\
\text { against foreigners and holders } \\
\text { of confidential letters }\end{array}$ & $\begin{array}{l}\text { Ratio of abuse of } \\
\text { document/confidential letter } \\
\text { annually }\end{array}$ \\
\hline 4 & $L, U, K$ and $P$ Tests & $\begin{array}{l}\text { 4. Implement the KRI Test } \\
\text { Activity (L) } \\
\text { 5. Implement the Aircraft Test } \\
\text { Activity (U) } \\
\text { 6. Implement the Special } \\
\text { Forces Test Activity (K) } \\
\text { 7. Implement the Base Test } \\
\text { Activity (P) }\end{array}$ & $\begin{array}{l}\text { The ratio of Glagaspur } L \text { Test } \\
\text { annually } \\
\text { The ratio of Glagaspur } U \text { Test } \\
\text { annually } \\
\text { The ratio of Glagaspur } K \text { Test } \\
\text { annually } \\
\text { The ratio of Glagaspur } P \text { Test } \\
\text { annually }\end{array}$ \\
\hline 5 & Courses, $L D D$, Binlat & $\begin{array}{l}\text { 8. Implement the courses } \\
\text { planned } \\
9 . \text { Implement the } L D D \\
\text { planned } \\
\text { 10. Implement the Binlat } \\
\text { planned } \\
\text { 11. Improvement of the } \\
\text { graduates }\end{array}$ & $\begin{array}{l}\text { Annual Course Ratio } \\
\text { Annual } L D D \text { Ratio } \\
\text { Annual Binlat Ratio } \\
\text { The ratio of passing participants } \\
\text { to total participants per year } \\
\text { The ratio of participants who } \\
\text { pass compared to the number of } \\
\text { participants annually }\end{array}$ \\
\hline 6 & $\begin{array}{l}\text { Implementation of } \\
\text { coach qualification } \\
\text { standards }\end{array}$ & $\begin{array}{l}\text { 12. Increasing the number of } \\
\text { Instructor Qualifications }\end{array}$ & $\begin{array}{l}\text { The ratio of the instructor is } \\
\text { constant compared to the number } \\
\text { of instructors }\end{array}$ \\
\hline 7 & Press Fulfillment & $\begin{array}{l}\text { 13. The fulfillment of military } \\
\text { personnel } \\
\text { 14. The fulfillment of civil } \\
\text { servants personnel }\end{array}$ & $\begin{array}{l}\text { The ratio of the military } \\
\text { personnel in the table of } \\
\text { organization and in the real } \\
\text { condition }\end{array}$ \\
\hline
\end{tabular}




\begin{tabular}{|c|c|c|c|}
\hline & & & $\begin{array}{l}\text { The ratio of the civil servant } \\
\text { personnel in the table of } \\
\text { organization and in the real } \\
\text { condition }\end{array}$ \\
\hline 8 & $\begin{array}{l}\text { Improvement of } \\
\text { Discipline }\end{array}$ & $\begin{array}{l}\text { 15. Reducing the number of } \\
\text { violations by personnel }\end{array}$ & $\begin{array}{l}\text { The ratio of the number of } \\
\text { violation annually }\end{array}$ \\
\hline 9 & $\begin{array}{l}\text { Improvement of } \\
\text { English }\end{array}$ & $\begin{array}{l}\text { 16. Increasing the personnel } \\
\text { who pass the American } \\
\text { Language Course Placement } \\
\text { Test (ALCPT) }\end{array}$ & $\begin{array}{l}\text { The ratio of personnel who pass } \\
\text { ALCPT }\end{array}$ \\
\hline 10 & Physical Fitness & $\begin{array}{l}\text { 17. Increasing the grades of } \\
\text { physical fitness }\end{array}$ & $\begin{array}{l}\text { The ratio of personnel who pass } \\
\text { the physical test }\end{array}$ \\
\hline 11 & $\begin{array}{l}\text { Improvement of } \\
\text { Character-Building }\end{array}$ & $\begin{array}{l}\text { 18. Decreasing the number of } \\
\text { divorce }\end{array}$ & The ratio of divorced personnel \\
\hline 12 & $\begin{array}{l}\text { Management of } \\
\text { stationery }\end{array}$ & 19. Distribution of stationery & $\begin{array}{l}\text { The ratio of stationery received } \\
\text { annually }\end{array}$ \\
\hline 13 & $\begin{array}{l}\text { Report of State } \\
\text { Possessions } \\
\text { Accounting System } \\
(\text { Simak } B M N)\end{array}$ & $\begin{array}{l}\text { 20. The completion of Simak } \\
B M N \text { report }\end{array}$ & The ratio of report made \\
\hline 14 & $\begin{array}{l}\text { Addition of } \\
\text { Instructional } \\
\text { Equipment }\end{array}$ & $\begin{array}{l}\text { 21. The fulfillment of } \\
\text { Instructional Equipment } \\
\text { needed }\end{array}$ & $\begin{array}{l}\text { The ratio of Instructional } \\
\text { Equipment supported }\end{array}$ \\
\hline 15 & $\begin{array}{l}\text { Development Planning } \\
\text { (Renbang) }\end{array}$ & $\begin{array}{l}\text { 22. The proposal of } \\
\text { Development Planning }\end{array}$ & $\begin{array}{l}\text { The ratio of proposed and } \\
\text { realized development }\end{array}$ \\
\hline 16 & $\begin{array}{l}\text { Budgeting } \\
\text { Management }\end{array}$ & 23. Punctual budget allocation & The ratio of annual used budget \\
\hline 17 & Software Training & $\begin{array}{l}\text { 24. Upgrading of the existing } \\
\text { software }\end{array}$ & The ratio of upgraded software \\
\hline 18 & $\begin{array}{l}\text { Completion of the } \\
\text { Curriculum }\end{array}$ & $\begin{array}{l}\text { 25. The improvement of } \\
\text { Instruction Packages }(P I)\end{array}$ & $\begin{array}{l}\text { The ratio of Instruction } \\
\text { Packages }(P I) \text { making }\end{array}$ \\
\hline
\end{tabular}

\subsection{KPI Validation Test}

KPI validation is a process to ensure and prove the correctness and accuracy of an indicator towards the real system. This validation is significant because the indicators in the performance measurement system of KOLAT KOARMATIM should really be accountable in terms of truth and accuracy. The validation is carried out by three officers, namely:

- KOLAT KOARMATIM Commander: Navy Colonel (P) O.C Budi Susanto

- KOARMATIM Operational Aid Officer for Planning (Pabanrensops): Navy Lieutenant Colonel (P) Bambang Warsito

- KRI Dewaruci Commander: Navy Lieutenant Colonel (P) Widyatmoko Baruno Aji

\subsection{Specification of KPI}

The KPI specification process is performed to determine a clear description of KPI objectives, linkage to the objectives, targets and formula thresholds/ways of measuring KPIs, frequency measurement, review frequency of who and what they are doing. The following is KPI predetermined specification as in Table 5. 
Table 5. KPI Specification of KOLAT KOARMATIM

\begin{tabular}{|l|l|}
\hline \multicolumn{1}{|c|}{ No. of KPI } & \multicolumn{1}{c|}{$\mathbf{1}$} \\
\hline Description & Personnel Safety \\
\hline Objective & Measuring the level of security against foreigners \\
\hline Linkage to the objective & $\begin{array}{l}\text { Personnel losses caused by the negligence of soldiers of } \\
\text { KOLAT KOARMATIM or external personnel. }\end{array}$ \\
\hline Threshold target & There is no loss of personnel due to negligence \\
\hline Measurement formula & $\begin{array}{l}\text { Ratio of strangers abusing and visiting KOLAT } \\
\text { KOARMATIM }\end{array}$ \\
\hline Measurement frequency & 1 year \\
\hline Review frequency & 1 year \\
\hline The unit who measure & $\begin{array}{l}\text { KOLAT KOARMATIM Chief of Security Unit } \\
\text { (Kasatpam) }\end{array}$ \\
\hline Data source & $\begin{array}{l}\text { KOLAT KOARMATIM Chief of Security Unit } \\
\text { (Kasatpam) }\end{array}$ \\
\hline
\end{tabular}

\subsection{DEMATEL Data Processing}

The fulfillment of DEMATEL questionnaire was done by expert respondents, in this case, Commanders of KRI and Glagaspur, Sea Operation Assistance (Duk Opsla), KOARMATIM Operational Aide Officer for Planning, Maritime Security Unit Chief (Dansatkamla). The condition scale is numbered from $0-4$; scale 0 indicates no association at all, scale 1 indicates a very small degree of influence among the evaluation criteria, scale 2 shows the relative medium degree of influence among the evaluation criteria, scale 3 shows a large degree of influence among the evaluation criteria, and the scale 4 shows the degree of enormous influence among the evaluation criteria. Figure 3 below presents the result of data processing using DEMATEL and determination of a threshold.

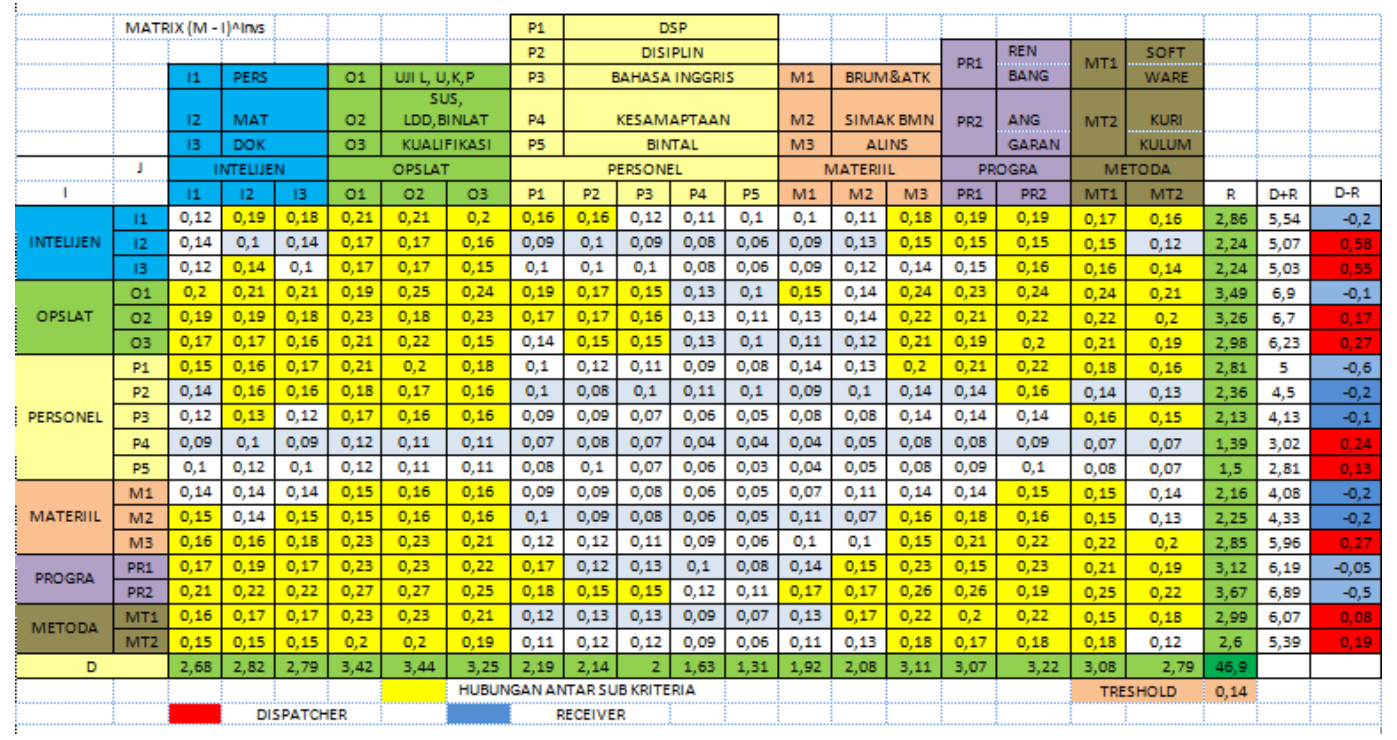

Figure 3. Results of DEMATEL Data Processing and Determination of Threshold 


\subsection{Data Collection and Processing using ANP}

Based on the results of data collection using DEMATEL, it can be seen that the ANP network modeling of the criteria KOLAT KOARMATIM Performance Measurement is using the Super Decision Software. The results are divided into two: considered to be the dominant criteria (Dispatcher category), and Receiver category that is not considered a priority to be analyzed. Based on the DEMATEL data processing on total association matrix (Matrix S), the association network model on the ANP method can be determined. ANP network can be seen in Figure 4.

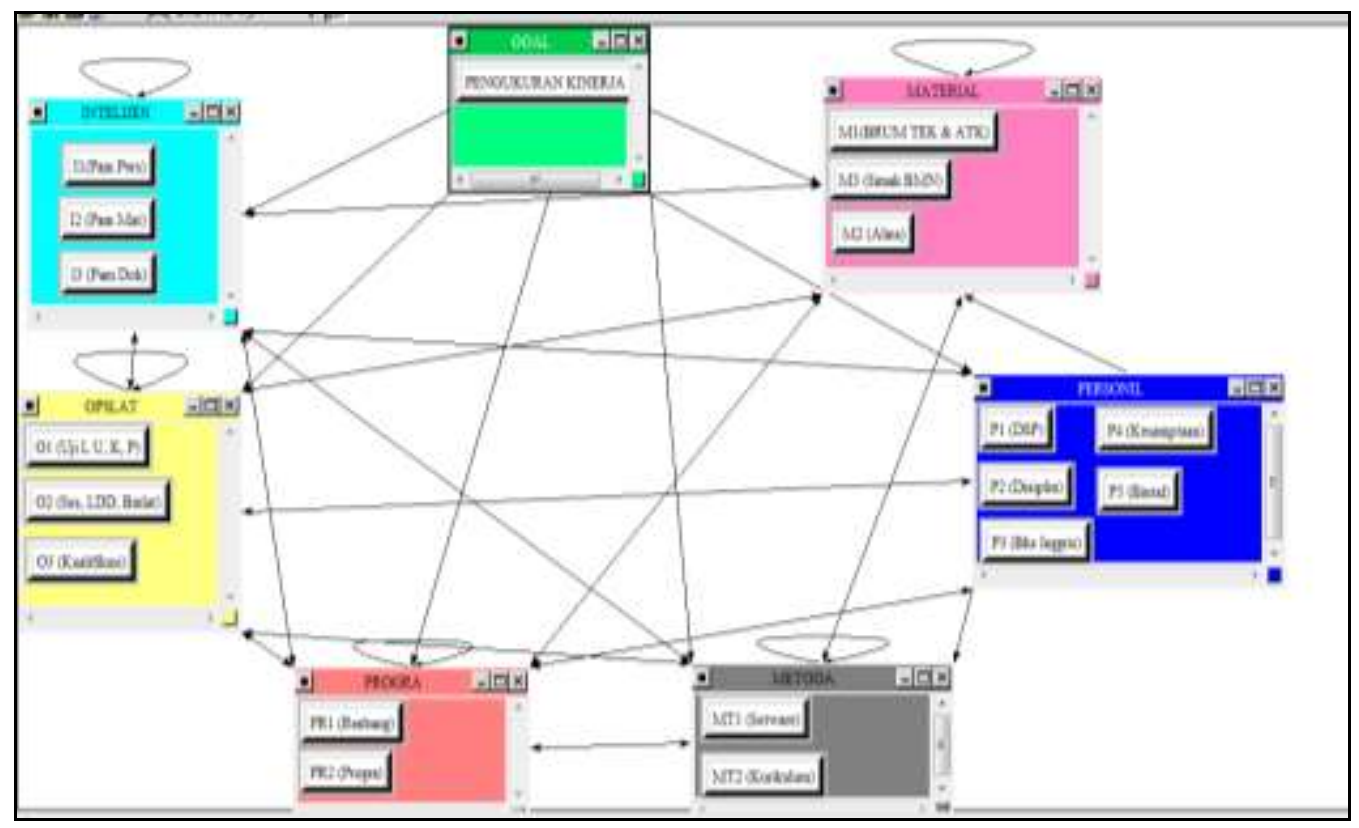

Figure 4. ANP Model of Kolat Performance Measurement

Table 6. Quantity of Each KPI

\begin{tabular}{|l|c|}
\hline \multicolumn{1}{|c|}{ KPI } & Relative Quantity \\
\hline No Press Sabotage & 0.0265 \\
\hline No material loss & 0.0567 \\
\hline No document loss & 0.0351 \\
\hline KRI Test (L) & 0.0285 \\
\hline Aircraft Test (U) & 0.0285 \\
\hline Special Force Test (K) & 0.0285 \\
\hline Base Test (P) & 0.0285 \\
\hline Implementation of Courses & 0.0309 \\
\hline Implementation of LDD & 0.0309 \\
\hline Implementation of Binlat & 0.0309 \\
\hline Improvement of Applicants' Interest & 0.0309 \\
\hline Improvement of Qualification Standards & 0.0707 \\
\hline Fulfillment of Military Personnel & 0.0090 \\
\hline Fulfillment of Civil Servant Personnel & 0.0090 \\
\hline Reducing Personnel' Abuse & 0.0291 \\
\hline Increase of the personnel who pass ALCPT & 0.0182 \\
\hline
\end{tabular}




\begin{tabular}{|l|c|} 
Distribution of stationery & 0.0135 \\
\hline The completion of Simak BMN & 0.0059 \\
\hline $\begin{array}{l}\text { The fulfillment of proposed Instructional } \\
\text { Equipment }\end{array}$ & 0.0919 \\
\hline Development Completion & 0.0614 \\
\hline Budget Allocation & 0.1846 \\
\hline Software Upgrade & 0.0933 \\
\hline Creation of Instruction Package & 0.0574 \\
\hline
\end{tabular}

\subsection{Scoring System Analysis Using OMAX Method and Traffic Light}

The scoring system was conducted to indicate the value of the achievement of each KPI of the objectives that have been identified, processed, and measured in the previous sub-section (See Table 6 above). From the achievement target results of KOLAT KOARMATIM, then the overall quantity is calculated by the Objective Matrix (OMAX) method and the Traffic Light System. From the quantifying results, the quantity of KOLAT KOARMATIM overall performance by the division of Traffic Light System is shown in the Table 7 below:

Table 7. KPI Quantifying Results of Kolat 2015

\begin{tabular}{|c|c|c|c|}
\hline RESULT & NO OF KPI & KPI & QUANTITY \\
\hline \multirow{11}{*}{ 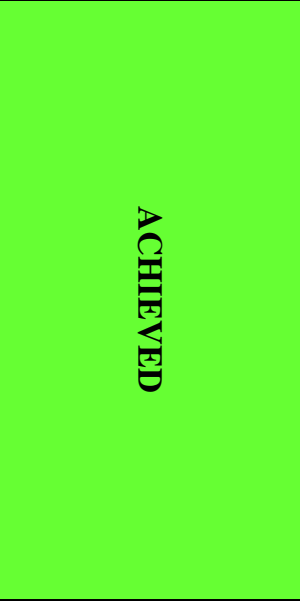 } & KPI 1 & No Press Sabotage & 0.265 \\
\hline & KPI 2 & No material loss & 0.567 \\
\hline & KPI 3 & No document loss & 0.351 \\
\hline & KPI 5 & $K R I$ Test (L) & 0.285 \\
\hline & KPI 6 & Aircraft Test (U) & 0.285 \\
\hline & KPI 11 & Special Force Test (K) & 0.309 \\
\hline & KPI 15 & Base Test $(\mathrm{P})$ & 0.233 \\
\hline & KPI 17 & Implementation of Courses & 0.135 \\
\hline & KPI 18 & Implementation of $L D D$ & 0.059 \\
\hline & KPI 19 & Implementation of Binlat & 0.919 \\
\hline & KPI 21 & Improvement of Applicants' Interest & 1.846 \\
\hline \multirow{11}{*}{ 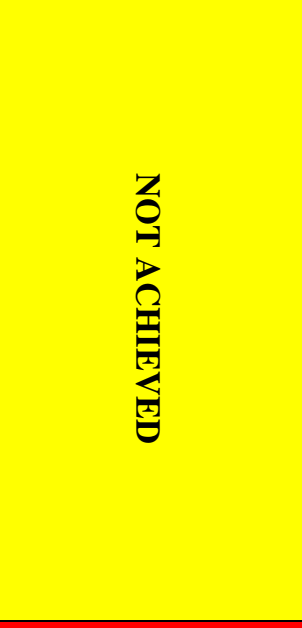 } & KPI 7 & Improvement of Qualification Standards & 0.171 \\
\hline & KPI 8 & Fulfillment of Military Personnel & 0.124 \\
\hline & KPI 9 & Fulfillment of Civil Servant Personnel & 0.124 \\
\hline & KPI 10 & Reducing Personnel' Abuse & 0.216 \\
\hline & KPI 12 & Increase of the personnel who pass ALCPT & 0.424 \\
\hline & KPI 13 & Distribution of stationery & 0.054 \\
\hline & KPI 14 & The completion of Simak BMN & 0.045 \\
\hline & KPI 16 & $\begin{array}{l}\text { The fulfillment of proposed Instructional } \\
\text { Equipment }\end{array}$ & 0.073 \\
\hline & KPI 20 & Development Completion & 0.430 \\
\hline & KPI 22 & Budget Allocation & 0.467 \\
\hline & KPI 23 & Software Upgrade & 0.229 \\
\hline BELOW TARGET & KPI 4 & $K R I(\mathrm{~L})$ Test & 0.086 \\
\hline \multicolumn{3}{|c|}{ TOTAL SCORE } & 7.697 \\
\hline
\end{tabular}


Table 7 above clearly shows KOLAT KOARMATIM performance achievement in 2015; of 23 KPIs, the performance measurement can be explained as follows:

a. There are 11 green KPIs with a threshold of 8 to 10; it means the achievement of a KPI has been reached.

b. There are 11 yellow KPIs with a threshold of 4 to 7 ; it means the achievement of a KPI is not reached, even though the value is close to the target.

c. There is 1 red KPI with a threshold of less than or equal to 3; it means the achievement of a KPI is below the target set by KOLAT KOARMATIM.

The overall score of the KOLAT KOARMATIM performance measurement is 7.697; which means the target of performance measurement (achievement) still has not been achieved despite nearing the desired threshold target (See Table 8).

Table 8. Quantifying Results of Kolat KPI 2016

\begin{tabular}{|c|c|c|c|}
\hline RESULT & $\begin{array}{l}\text { NO OF } \\
\text { KPI }\end{array}$ & KPI & QUANTITY \\
\hline \multirow{16}{*}{ 苗 } & KPI 1 & No Press Sabotage & 0.265 \\
\hline & KPI 2 & No material loss & 0.567 \\
\hline & KPI 3 & No document loss & 0.351 \\
\hline & KPI 4 & $K R I$ Test (L) & 0.285 \\
\hline & KPI 5 & Aircraft Test (U) & 0.285 \\
\hline & KPI 7 & Special Force Test (K) & 0.257 \\
\hline & KPI 9 & Base Test $(\mathrm{P})$ & 0.247 \\
\hline & KPI 10 & Implementation of Courses & 0.309 \\
\hline & KPI 11 & Implementation of $L D D$ & 0.309 \\
\hline & KPI 15 & Implementation of Binlat & 0.291 \\
\hline & KPI 16 & Improvement of Applicants' Interest & 0.164 \\
\hline & KPI 17 & Improvement of Qualification Standards & 0.135 \\
\hline & KPI 18 & Fulfillment of Military Personnel & 0.059 \\
\hline & KPI 19 & Fulfillment of Civil Servant Personnel & 0.919 \\
\hline & KPI 21 & Reducing Personnel' Abuse & 1.846 \\
\hline & KPI 23 & Increase of the personnel who pass ALCPT & 0.459 \\
\hline \multirow{6}{*}{ 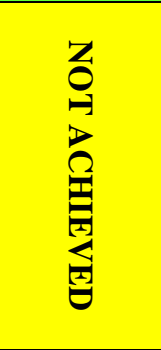 } & KPI 6 & Distribution of stationery & 0.143 \\
\hline & KPI 8 & The completion of Simak BMN & 0.185 \\
\hline & KPI 12 & $\begin{array}{l}\text { The fulfillment of proposed Instructional } \\
\text { Equipment }\end{array}$ & 0.424 \\
\hline & KPI 13 & Development Completion & 0.054 \\
\hline & KPI 14 & Budget Allocation & 0.045 \\
\hline & KPI 22 & Software Upgrade & 0.560 \\
\hline $\begin{array}{l}\text { BELOW } \\
\text { TARGET }\end{array}$ & KPI 20 & Development Planning & 0.184 \\
\hline \multicolumn{3}{|r|}{ TOTAL SCORE } & 8.344 \\
\hline
\end{tabular}

Table 8 above clearly shows KOLAT KOARMATIM performance achievement in 2016; of 23 KPIs, the performance measurement can be explained as follows:

a. There are 16 green KPIs with a threshold of 8 to 10; it means the achievement of a KPI has been reached.

b. There are 6 yellow KPIs with a threshold of 4 to 7; it means the achievement of a KPI is not reached, even though the value is close to the target. 
c. There is 1 red KPI with a threshold of less than or equal to 3; it means the achievement of a KPI is below the target set by KOLAT KOARMATIM.

The overall score of the KOLAT KOARMATIM performance measurement is 8.344 meaning that the target of performance measurement (achievement) has been achieved. This suggests that there is an increase in the performance of KOLAT KOARMATIM in 2016 compared to 2015; and it is expected that this condition will always be maintained for the coming period although there are some KPIs that should be noted not to decrease, and there are also KPIs that should receive serious attention in order not to be below the target.

\subsection{Discussion}

Based on the data processing results, the implementation and design of KOLAT KOARMATIM Performance Measurement with IPMS method, DEMATEL, ANP continued with scoring using OMAX and Traffic Light System, it could be concluded as follows:

a. From the KOLAT KOARMATIM Performance Measurement results using Integrated Performance Measurement System, it obtains 6 (six) criteria, 16 (sixteen) sub-criteria, and 23 (twenty three) KPIs which include 3 KPIs for intelligence criteria, 9 KPIs for operations and exercises criteria, 4 KPIs for personnel criteria, 3 KPI for material criteria, 2 KPIs for the program and budget criteria, 2 KPIs for method criteria.

b. From the measurement of 2015 performance conducted, it gains 7.697 of Total Performance Index as a result of scoring by using Objective Matrix (OMAX); while by using the Traffic Light System, the results are in the yellow category, that means the target of performance measurement (achievement) of 2015 was not achieved despite nearing the desired threshold target; there are 11 green KPIs which means the achievement of a KPI has been achieved; there are 11 yellow KPIs which means the achievement of a KPI is not achieved; and one red KPI which means the achievement of a KPI is below the set target.

c. From the measurement of 2016 performance conducted, it gains 8.344 of Total Performance Index as a result of scoring by using Objective Matrix (OMAX); while by using the Traffic Light System, the results are in green category, that means the target of performance measurement (achievement) has been achieved with a distribution; 16 green KPIs which means the achievement of a KPI has been achieved; there are 6 yellow KPIs which means the achievement of a KPI is not achieved; and one red KPI which means the achievement of a KPI is below the set target.

d. In the performance measurement in 2015 and 2016, there is an increase in total quantity of 0.647 , which means the performance measurement target of KOLAT KOARMATIM in 2016 has increased, although there is one KPI that is below the target; the $20 \mathrm{KPIs}$ of development planning. It is because the development planning decision is made in the level of Navy Headquarters (MABESAL).

e. Recommendations for improvements are not only given to KPIs that are below the target, but to all KPIs. They are expected to give positive feedback to the KOLAT KOARMATIM Commander.

f. In general, Kolat performance assessment is based on the expectations of stakeholders. Duties and responsibilities of KOLAT KOARMATIM can be carried out properly in accordance with the planning and implementation.

g. As a final conclusion to answer the questions on the formulation of the problem and the research objectives, KOLAT KOARMATIM Performance Measurement can be carried out by using the method of Integrated Performance Measurement System, DEMATEL, ANP, and continued by scoring using OMAX and Traffic Light System. 


\section{Conclusion and Recommendation}

This paper has presented the combination of DEMATEL, ANP, and IPMS methods for performance measurement system design. The method has been successfully designed at KOLAT KOARMATIM to analyze the achievement of the 2015 and 2016 Work Programs with 23 Key Performance Indicators (KPIs), based on stakeholders' requirements of KOLAT KOARMATIM. Based on the research conducted, several suggestions found in this study can be addressed to future researches as well as to the authorities of the decision maker, in this case, the Commander of KOLAT KOARMATIM: In the subsequent studies, they are suggested to integrate the performance measurement system with the evaluation system and information technology as a supporting means, so that the process of measurement and performance evaluation can be quickly updated. As suggestions for KOLAT KOARMATIM, the results of performance measurement system design conducted by the approach of Integrated Performance Measurement System may be the solution for the problems of measurement that has been done, but it requires that the data collection of the performance achievement value should be conducted continuously.

\section{Acknowledgement}

This research is supported by Research Grant from Sekolah Tinggi Teknologi Angkatan Laut, Indonesia.

\section{References}

[1] I. Vanany. "ANP pada Perancangan Sistem Pengukuran Kinerja (Studi Kasus pada P.T. X)", Journal Teknik Industri. vol. 5, no. 1, (2003), pp. 50-62.

[2] I. Vanany and D. Tanukhidah, "Perancangan dan Implementasi Sistem Pengukuran Kinerja dengan Metode Performance Prism pada Bisnis Hotel”, Jurnal Teknik Industri, Universitas Petra, (2004).

[3] I. Vanany, "Performance Measurement: Model dan Aplikasi (Revision Second Print)", Penerbit ITS Press, Surabaya, (2009).

[4] R. F. Speklé and F. H. Verbeeten, "The use of performance measurement systems in the public sector: Effects on performance", Management Accounting Research, vol. 25, no. 2, (2014), pp.131-146.

[5] L. Siham, B. J. Claude, G. Laurent, D. Yves and J. Zied, "Designing supply chain performance measurement and management systems: A systemic perspective", In Advanced Logistics and Transport (ICALT), 2015 4th International Conference on, IEEE, (2015), pp. 211-216.

[6] M. C. Wall, K. Kraus and M. Messner, "Performance measurement systems and the enactment of different institutional logics: insights from a football organization", Management Accounting Research, vol. 32, (2016), pp.45-61.

[7] F. Landy, S. Zedeck and J. Cleveland, "Performance measurement and theory", Taylor \& Francis, (2017).

[8] P. L. Indah, P. Suwignjo and I. Vanany, "Perancangan Sistem Pengukuran Kinerja dengan Balanced Scorecard: Bentuk, Mekanisme, dan Prospek Aplikasinya pada BUMN", Journal Ekonomi dan Bisnis Indonesia, vol. 12, no. 2, (2002).

[9] K. S. Robert and N. B. David, "Translating Strategy into Action: The balanced Scorecard", Harvard Business school Press, Boston, Massachusetts, (1996).

[10] K. S. Robert and N. B. David, "Linking the Balanced Scorecard to Strategy", California Management Review fall into Action, S., 1996. Balanced scorecard. Harvard Business School Press, Boston, MA, vol. 39 , no. 1, (1996).

[11] Martello, M., Watson, J.G. and Fischer, M.J., 2016. Implementing a balanced scorecard in a not-forprofit organization. Journal of Business \& Economics Research (Online), 14(3), p.61.

[12] Neely, A., Adams, C. and Crowe, P., 2001. The performance prism in practice. Measuring business excellence, 5(2), pp.6-13.

[13] Neely, A. and Adams, C., 2000. Perspectives on performance: the performance prism. Focus Magazine for the Performance Management Professional, 4.

[14] Neely, A.D., Adams, C. and Kennerley, M., 2002. The performance prism: The scorecard for measuring and managing business success. London: Financial Times/Prentice Hall.

[15] Kusuma, W. (2006). "Perancangan dan Pengukuran Kinerja dengan Menggunakan Metode Performance Prism di PT Kangsen Kenko Indonesia Cabang Surabaya", Proceeding of the National Seminar on Technology Management III Program MMT-ITS, Surabaya, February 4, 2006. 
[16] Anita (2003). "Perancangan dan Implementasi Sistem Pengukuran Kinerja Yayasan dengan Metode Integrated Performance Measurement System pada YDSF Surabaya”. Jurnal Industrial Engineering, RSI 658. 3125 Ani p, 2003.

[17] Bititci, U.S, Carrie A.S., McDevitt L. (1997). "Integrated Performance Measurement System: An Audit Development Guide", International Journal of Operations and Production Management, 17(5), pp.522534.

[18] Susetyo, J (2013). "Penerapan Sistem Pengukuran Kinerja Perusahaan dengan Metode Integrated Performance Measurement Systems (IPMS) pada PT X". Jurnal Teknologi, Volume 6 Nomor 1, Juni 2013, p. 98.

[19] Maulidia, F.R., Setyanto, N.W. and Rahman, A., 2014. Perancangan Sistem Pengukuran Kinerja Dengan Metode Integrated Performance Measurement System (IPMS) (Studi Kasus: KPRI Universitas Brawijaya). Jurnal Rekayasa dan Manajemen Sistem Industri, 2(1), pp.p1-10.

[20] Indrawati, I. (2005) "Perancangan dan Sistem Pengukuran Kinerja dengan Pendekatan IPMS" Undergraduete Thesis, Industrial Enginering, RSI 658.312 45 Ind p, 2005.

[21] Liang, T.L., Hsu, S.L., Huang, C.H. and Chen, M.T., 2013. A Study on the Causal Relationship of Evaluation and Selection Criteria for the Professional Capabilities in School's Administrative Operation. Journal of Applied Sciences, 13(3), pp.354-365.

[22] Tzeng, G.H., Chiang, C.H. and Li, C.W., 2007. Evaluating intertwined effects in e-learning programs: A novel hybrid MCDM model based on factor analysis and DEMATEL. Expert systems with Applications, 32(4), pp.1028-1044.

[23] Lin, R.J., 2013. Using fuzzy DEMATEL to evaluate the green supply chain management practices. Journal of Cleaner Production, 40, pp.32-39.

[24] Govindan, K., Khodaverdi, R. and Vafadarnikjoo, A., 2016. A grey DEMATEL approach to develop third-party logistics provider selection criteria. Industrial Management \& Data Systems, 116(4), pp.690722.

[25] Büyüközkan, G. and Güleryüz, S., 2016. An integrated DEMATEL-ANP approach for renewable energy resources selection in Turkey. International Journal of Production Economics, 182, pp.435-448.

[26] Bititci, U.S., Carrie, A.S., Turner, T. and Lutz, S., 1998. Integrated performance measurement systems: implementation case studies. In Strategic Management of the Manufacturing Value Chain (pp. 177-184). Springer US

[27] P. Suwignjo, U. Bititci, A. Carrie and T. Turner, "Performance measurement systems: auditing and prioritisation of performance measures", In Internation conference on Performance Measurement, (1998).

[28] U. S. Bititci, U. Turner and C. Begemann, "Dynamics of performance measurement systems", International Journal of Operations \& Production Management, vol. 20, no. 6, (2000), pp.692-704.

[29] E. Fontela and A. Gabus, "DEMATEL Report No. 2. Analytical Methods, Battelle", (1973).

[30] W. W. Wu and Y. T. Lee, "Developing global managers' competencies using the fuzzy DEMATEL method", Expert systems with applications, vol. 32, no. 2, (2007), pp.499-507.

[31] M. S. Ranjbar, M. A. Shirazi and M. L. Blooki, "Interaction among intra-organizational factors effective in successful strategy execution: An analytical view”, Journal of Strategy and Management, vol. 7, no. 2, (2014), pp.127-154.

[32] T. L. Saaty, "Analytic network process", In Encyclopedia of Operations Research and Management Science, Springer US, (2001), pp. 28-35.

[33] D. Balkan, "Enterprise productivity measurement in services by OMAX (Objective Matrix) method and an application with Turkish emergency service", In Reser Conference, Productivity of Services Next Gen-Beyond Output/Input. Hamburg, (2011), pp. 1-13.

[34] W. Wiwin, "Pengembangan Model Risiko pada Implementasi Lean Manufacturing di P.T. Dirgantara Indonesia (Indonesian AeroSpace) dengan Pendekatan Terintegrasi”, (2015). 